\title{
BUTTERFLIES OF NORTHEASTERN ALBERTA
}

CHARLES D. BIRD, Box 165, Mirror, Alberta TOB 3C0; GERALD J. HILCHIE, 301, 8524 - 103 Street, Edmonton, Alberta T6E 4B5; NORBERT G. KONDLA, Alberta Energy and Natural Resources, 530 - 8th Street South, Lethbridge, Alberta T1J 2J8; WAYNE W. SMITH, 8220 Elbow Drive SW, Calgary, Alberta T2V 1K4; ELSIE KUYT, 3810 - 103B Street, Edmonton, Alberta T6J 2X9; JAMES K. RYAN, Ryan and Hilchie Biological Consultants Ltd., 10948 - 89 Avenue, Edmonton, Alberta T6G OZ5 and TERRY W. THORMIN, Provincial Museum of Alberta, Edmonton, Alberta T5N OM6

The butterflies and skippers of northeastern Alberta (Map 1) are described herein. The area is defined as that region from $56^{\circ} \mathrm{N}$ latitude north to the Northwest Territories border and from Saskatchewan west to the 5th Meridian (114 ${ }^{\circ}$ longitude). This region has received considerable attention of late due to its oil sand deposits.

\section{Description of the Area}

Butterfly diversity is linked with both the physical and biotic diversity of an area. Four major units occur in the boreal forest of northern Alberta; boreal mixed wood (most of study area), boreal-subarctic jackpine sand plains, boreal-subarctic alluvial lowlands, and subarctic woodland. These may be subdivided into 14 vegetation associations (Table 1). Different species of butterflies predominate in each e.g. Jutta Arctic (Oeneis jutta), Mancinus Alpine (Erebia disa), Frigga Fritillary (Bo/oria frigga saga), and Yukon Blue (Plabejus optilete) may be found flying in black spruce while upland forest is home for Macoun's Arctic (Oeneis macounii), Chryxus Arctic (O. chryxus), and Tiger Swallowtail (Papilio glaucus). Butterflies depend on specific members of the plant community for larval food and to a esser extent, adult food.

Though somewhat dated, H.M. Raup's publication on the vegetation and flora of Wood Buffalo National Park is the best single account on the botany of northeastern Alberta and should be consulted by anyone interested in the plants of the area. ${ }^{14}$

Physiographic variation affects plant diversity and subsequently butterfly diversity. Major relief features in the area are five highland areas; Birch Mountains $(520 \mathrm{~m})$, Stoney Mountain $(760 \mathrm{~m})$, Muskey Mountain $(580 \mathrm{~m})$ and the eastern escarpment of the Caribou Mountains. The Fort Hills rise more than $100 \mathrm{~m}$ above the Athabasca River. Low lying areas between highlands and river flood plains are composed of flat to rolling terrain. In the province's northeast corner numerous small lake and areas of bare rock characterize the Canadian Shield. A large portion of the south and west region is underlain by oil sand deposits, which are being mined and processed by Suncor and Syncrude oil extraction plants.

All creeks arising in the study area are ultimately drained by the Athabasca and Peace rivers via the Slave River drainage. Much of the land is poorly drained, resulting in an abundance of marshes, bogs and fens.

Climate is characterized by long cold winters with short summers. Temperatures average from a maximum of $27^{\circ} \mathrm{C}$ in July to an average minimum of -23 to $-30^{\circ} \mathrm{C}$ in January. The frost free period ranges from 80 to 100 days per year with an annual precipitation 


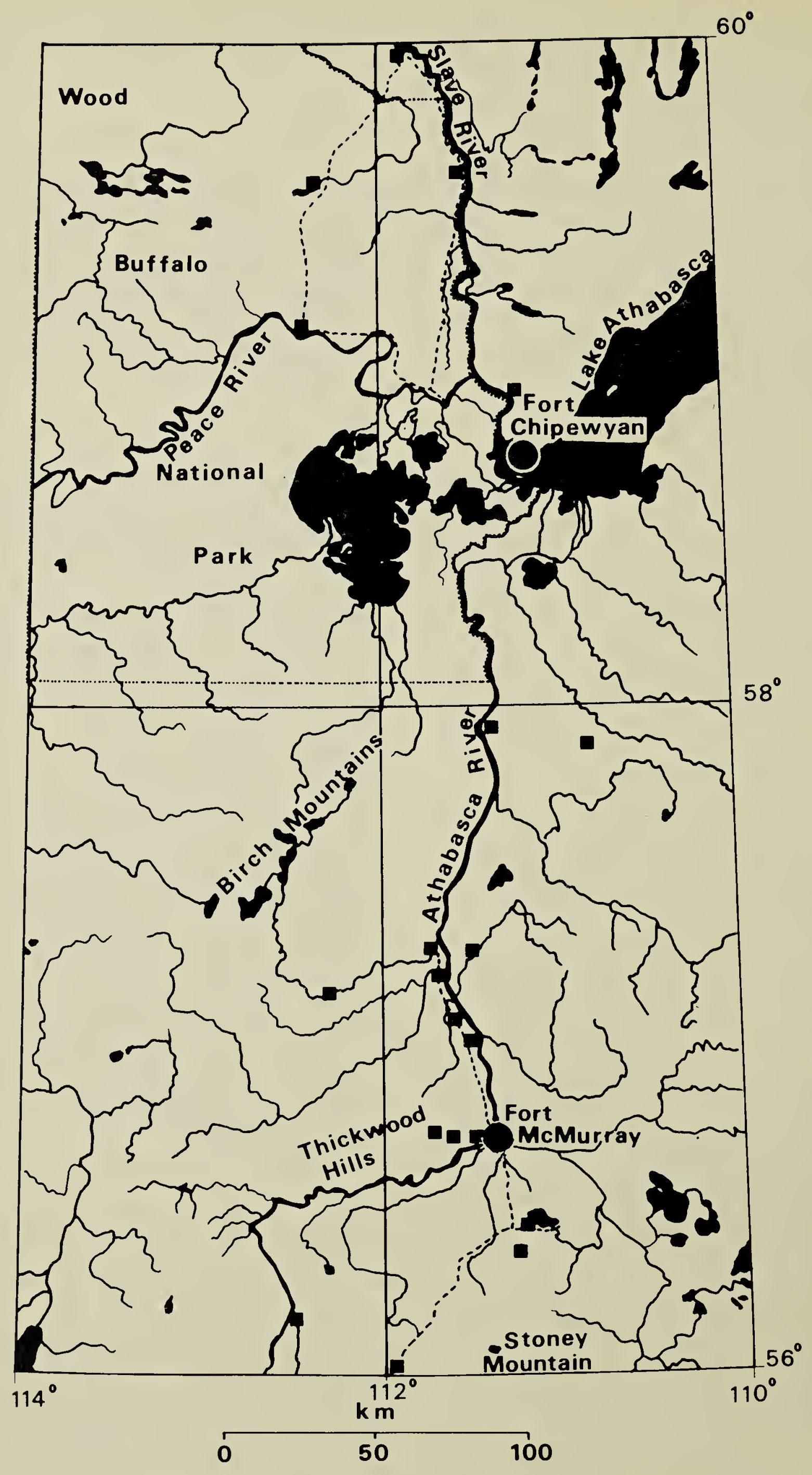

Map of northeastern Alberta. Collection sites are indicated by solid squares. 
Table 1. VEGETATION TYPES OF NORTHEAST ALBERTA ADAPTED FROM THOMPSON et al., 1978.

Vegetation Association

Bottomland Communities

Bottomland and riparian forest

Deciduous shrub wetland

Upland Communities

White Spruce-aspen, spruce dominated

White Spruce-aspen, mixed

White Spruce-aspen, aspen dominated

Mixed coniferous

Jack Pine

Upland open

Mixed forest

Wetland Communities Fen

Black Spruce bog

Semi-open Black Spruce, Tamarack bog forest

Lightly forested Tamarack and open muskeg

Disturbed Communities

Non-vegetated

\section{Composition}

Balsam Poplar, Trembling Aspen, White Spruce, willow, alder, Paper Birch willow, alder, Dwarf Birch, immature Trembling Aspen, Paper Birch

White Spruce, Trembling Aspen,

White Spruce, Jack Pine, Trembling Aspen

Trembling Aspen, White Spruce, Jack Pine

Black Spruce, Jack Pine, White Spruce

Jack Pine, Black Spruce, White Spruce, Trembling Aspen grasses, low herbs and shrubs Trembling Aspen, White Spruce, Black Spruce, Tamarack, Paper Birch, Jack Pine, alder

sedges, rushes, low scattered shrubs, tall shrubs

Black Spruce, sphagnum mosses

Black Spruce, Tamarack, sphagnum mosses, sedges, rushes

Tamarack, Black Spruce, low shrubs, sphagnum mosses

recent slides, clearings, slumps with sparse vegetation, burns

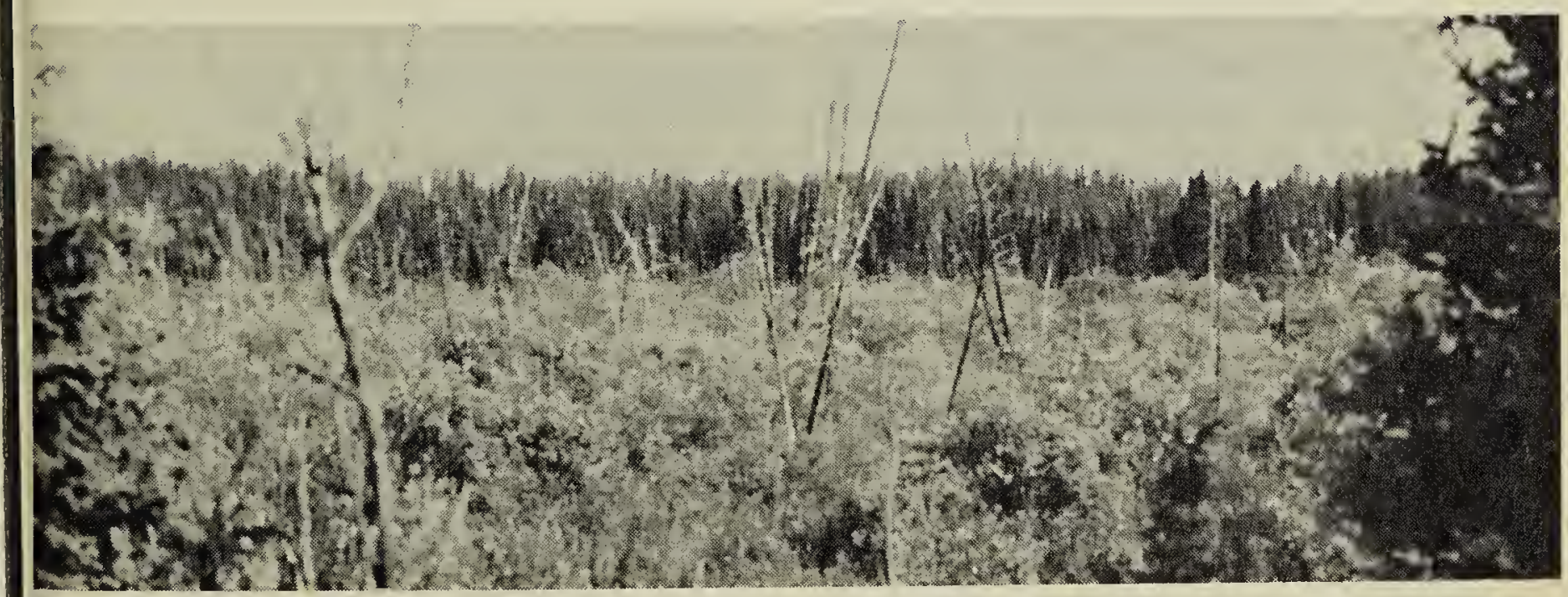

Thickwood Hills - burned spruce bog as willow-alder shrub wetland. Ryan \& Hilchie Biological Consultants Ltd. 


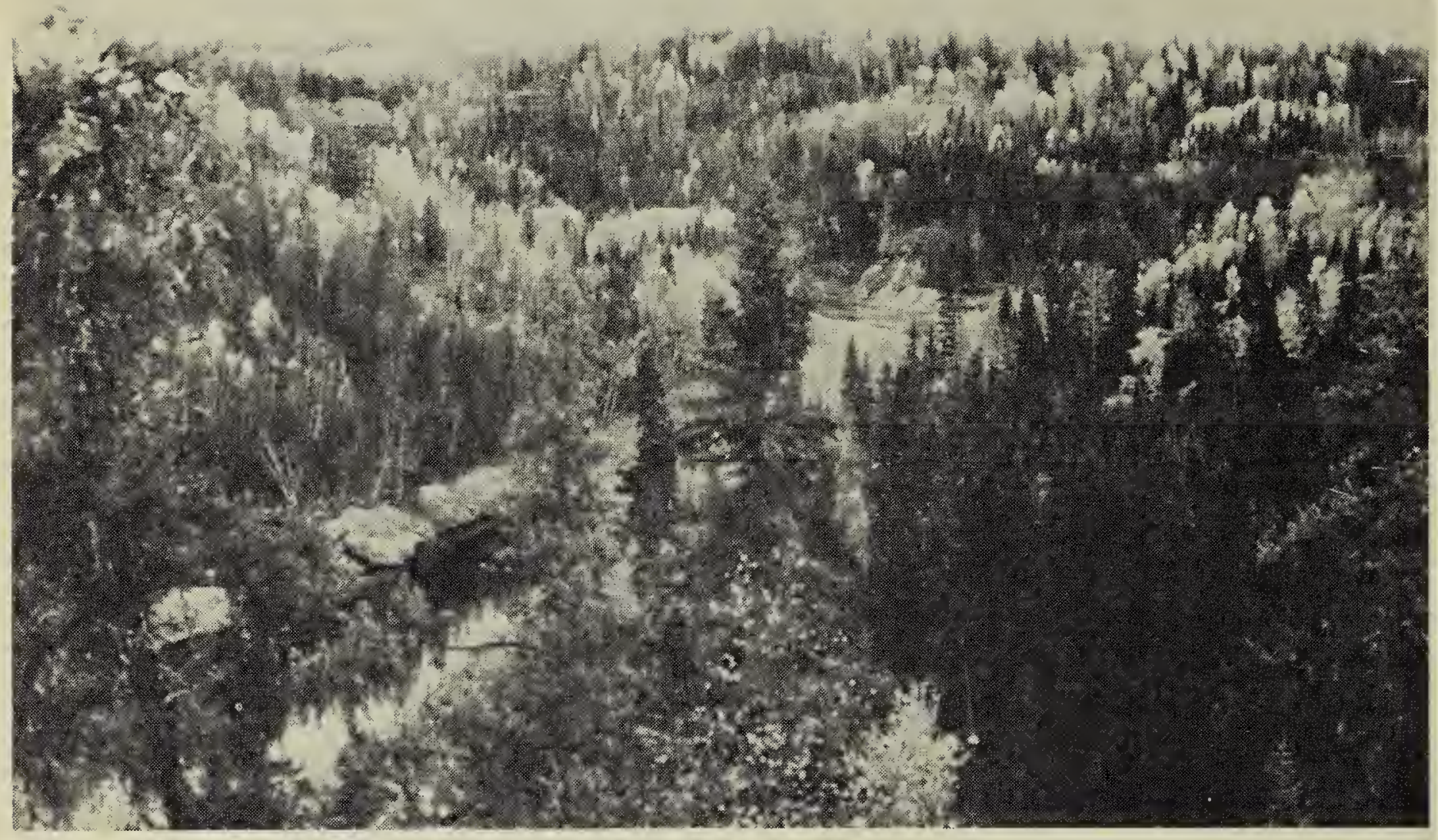

MacKay River near Fort MacKay - in autumn. Ryan \& Hilchie Biological Consultants Ltd.

range of $36 \mathrm{~cm}$ in the Peace-Athabasca Delta to $56 \mathrm{~cm}$ at Stoney Mountain. Seasonal fluctuations in climate affect changes in distribution and abundance of butterflies. Climate as a whole affects the distribution of host plants and subsequently the distribution patterns of butterflies.

\section{Butterfly Faunal Source Regions}

During the Wisconsinian glacial, northeastern Alberta was under the Laurentide Ice sheet. Animals colonized the region following retreat of the ice sheet and subsequent recolonization by plants. Butterflies may be associated with different faunal source areas. Species associated with the boreal biome include Mancinus Alpine (Erebia disa), Red-disced Alpine (E. dis-

a EDITOR'S NOTE: Mariposa Copper (Reakirt's Copper) has been taken in central Saskatchewan eastward to the northeast corner of Prince Albert National Park. - W. Harris. coidalis), Jutta Arctic (Oeneis jutta), Chryxus Arctic (O. chryxus caryi), Giant Sulpher (Colias gigantea gigantea), Eastern Pine Elfin (Callophrys niphon clarki), Hudsonian Old World Swallowtail (Papilio machaon hudsonianus) and Frigga Fritillary (Boloria frigga saga).

Hecla Sulpher (Colias hecla) and Yukon Blue (Plebejus optilete yukona) are correlated with a northern sub-arctic refugium, dispersing southward and eastward into the study area.

Two-banded Checkered Skipper (Pyrgus ruralis), California White (Pieris sisymbrii), Creusa Marble (Euchloe creusa), and Mariposa Copper

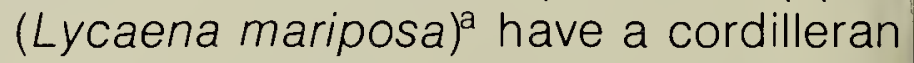
origin, and occur here at the northeast limit of their range. 


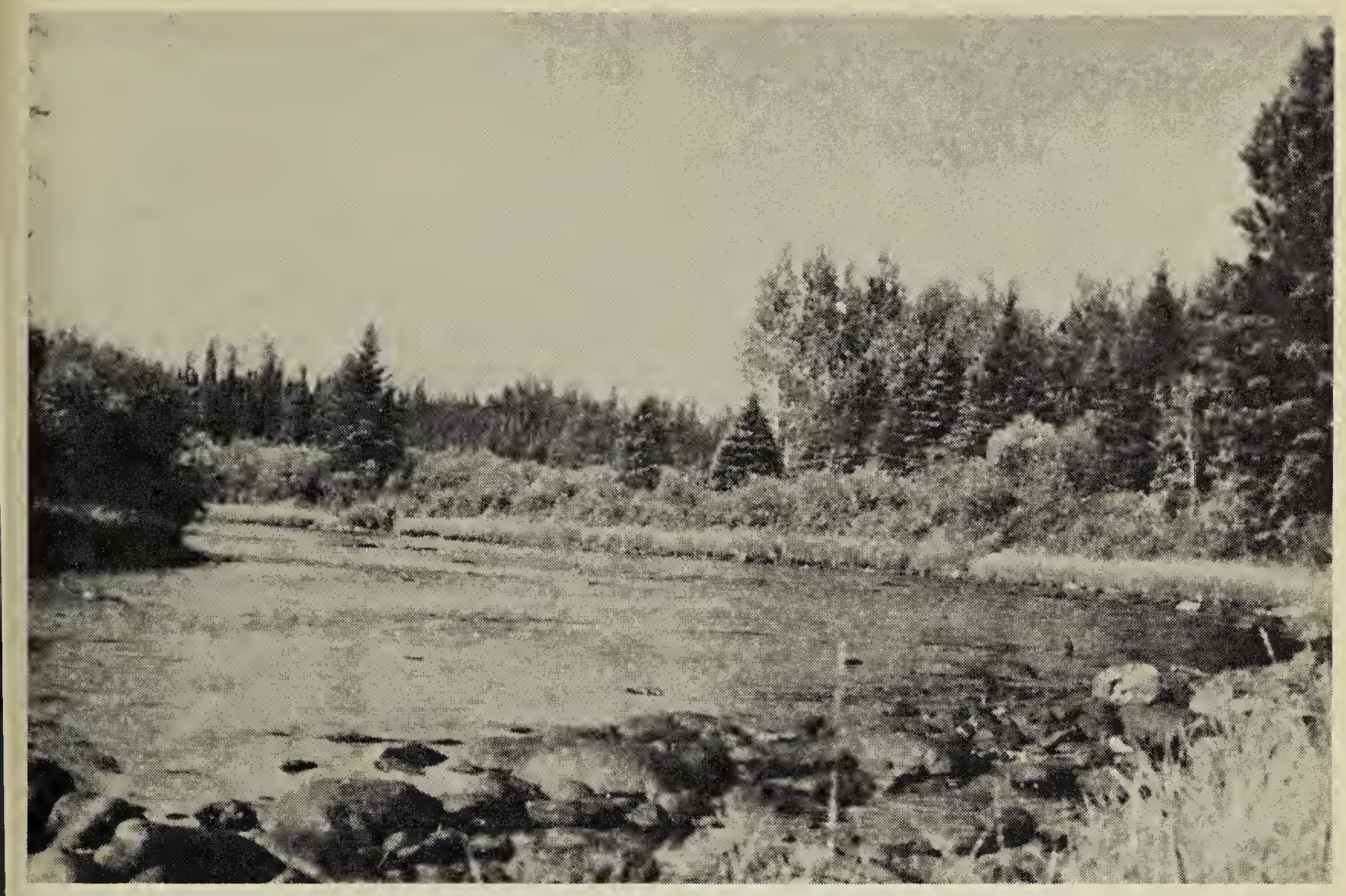

Ells River near SE escarpment of Birch Mountains.

Ryan \& Hilchie Biological Consultants Ltd.

During the Hypsithermal, climatic conditions were warmer and drier than present. Northward extensions of grassland species were possible. Under present climatic regimes, dry, grass covered hillsides are found along the Athabasca River, some of its larger tributaries, and in portions of the Birch Mountains. Sandy, open jackpine forest with active sand dunes form an extensive plain east of the Athabasca River. Prairie-like grasslands (Wood Buffalo prairie) are found north of the Birch Mountains. Prairie species found in these habitats include Peck's Skipper (Polites coras), Common Checkered Skipper (Pyrgus communis), and Small Wood Nymph (Cercyonis oetus charon), Ochre Ringlet (Coenonympha ochracea mackenziei), is closely related to the prairie dwelling ringlets. Other rairie insects have been collected and more discoveries are expected. ${ }^{16}$

Recent disturbance by man (roads, bardens, farms) has permitted colonization by the Cabbage White (Pieris rapae) and Yellow Alfalfa Butterfly (Colias philodice eriphyle).

Some species cannot be identified as being associated with a specific biome because they are ubiquitous, and it can be inferred that they survived the Wisconsinian south of the ice sheet. Such species are Mourning Cloak (Nymphalis antiopa), Milbert's Tortoise Shell (N. milberti), Pearl Crescent (Phyciodes tharos), Silvery Blue (Glaucopsche lygdamus), Spring Azure (Celastrina argiolus) and Western Tailed Blue (Everes amyntula).

The composite we see today is a result of thousands of years of migrations, colonization and changes in the position of vegetation zones. High vagility and lack of fossil evidence impairs reconstruction of butterfly faunal changes in the study area. Present distributions may be used to deduce past biogeographical events. 


\section{History}

The earliest collections in the area were a few made by Mrs. Christina Ross, wife of Bernard Ross who was in charge of the Mackenzie District for the Hudson Bay Company, at Smith Portage in 1862 and then sent to W.H. Edwards. He named Christina Sulpher (Colias alexandra christina) in her honor.

Miss Elizabeth Taylor made a trip down the Athabasca, Slave and Mackenzie Rivers in 1892 and collected a number of butterflies for the British Museum. ${ }^{1}$

Merritt Cary, of the U.S. Biological Survey, in company with Edward A. Preble made numerous collections along the Athabasca and Slave Rivers in 1903 (Cary 1907).

Later collections were made by $J$. Russell at Fort Chipewyan in 1927; G. Cinnamon at House River in 1932 and 1933; G. E. Ball and W. J. Brown at Fort McMurray in 1953; E. Gautreau at Peace Point in 1967; Elsie Kuyt in Wood Buffalo National Park in $1973^{13}, 1974$, 1975 and 1976; and Wayne W. Smith at Gregoire Lake in 1976. F. Sperling collected at Fort McMurray and Stoney Mountain on May 30, 1981. Work for the Provincial Museum permitted $T$. Thormin and $L$. Bogaert to collect in the area south of Fort Smith from June 1723, 1981.

Development of petroleum reserves from tar sands led to research which resulted in recent collections by $W$. B. Porter 20 miles north of Fort McMurray in 1974; N. G. Kondla at the Home Oil Lease a few miles ENE of Fort Mackay in 1975; Wayne Smith at the Shell Test Pit, 40 miles ENE of Fort Mackay in 1977; extensive studies by G. J. Hilchie and J. K. Ryan in 1978-1979 at Mildred Lake, Fort Mackay, Ellis River, Thickwood Hills, Tar Island (Suncor), Fort McMurray, Mariana Lake and Stoney Mountain Lookout; and Ber- nadette Otto at Mildred Lake and the Thickwood Hills in 1979.

\section{Species List}

The present study is a sequel to that of west-central Alberta by Case and Bird. ${ }^{4}$ This list uses the same format and most of the nomenclature of $R$. R. Hooper's "Butterflies of Saskatchewan' rather than that of Miller and Brown who propose many changes in the scientific names of local butterflies. ${ }^{12}$ The collectors names are given in brackets. Those collections made by Hilchie and Ryan are abbreviated to "HR". Collections made by Bogaert, Kuyt and Thormin in Alberta $1-13 \mathrm{~km}$ south of Fort Smith, N.W.T. are listed simply as Fort Smith.

\section{Hesperiidae - Skippers}

ROADSIDE SKIPPER (Amblyscirtes vialis). 6 June-23 July. A common species of clearings, trails and roadsides. Known from Fort MacKay (Kondla), Fort Smith (Thormin), Mildred Lake (HR), Shell Pit (Smith), and Thickwood Hills (HR).

PECK'S SKIPPER (Polites coras). 26 July. Rare. Found in clearings and grasslands. Known from Mildred Lake (HR).

ARCTIC SKIPPER (Carterocephalos palaemon). 29 May-14 July. A common species of open woods, roadsides and clearings. Known from Fort Mackay (Kondla), Fort McMurray (Ball, Brown), Fort Smith (Thormin), Gregoire Lake (Smith), Mildred Lake (HR), Pine Lake (Kuyt), and Shell Pit (Smith). Northern material may belong to ssp. mackenziei while the remainder is probably ssp. mandan.

ALPINE CHECKERED SKIPPER (Pyrgus centaureae freija). 5 July. Rare. Found in open woods and along roadsides. Known from the Thickwood Hills (HR). This is the first published record of this subspecies from Alberta.

TWO-BANDED CHECKERED SKIPPER (Pyrgus ruralis). 12 June. Rare. Known only from Smith Portage (Cary). A considerable range extension to the northeast, if correctly determined. 
Cary's specimens were deposited at the United States National Museum but a recent search revealed no voucher to back up this report. ${ }^{3}$ Further documentation is needed.

COMMON CHECKERED SKIPPER (Pyrgus communis communis). 7 July. Rare. A species of dry prairie grasslands. Its discovery at Mildred Lake (HR) is a remarkable northern range extension. E. M. Pike has recently found it in relict Peace River grasslands (pers. comm.).

DREAMY DUSKY WING (Erynnis icelus). 10 May-20 June. A common skipper of open woods and roadsides. Known from Fort Mackay (HR, Kondla), Gregoire Lake (Smith), House River (Cinnamon), Mildred Lake (HR), Pine Lake (Kuyt), Shell Pit (Smith), and Smith Portage (Cary, Preble).

PERSIUS DUSKY WING (Erynnis persius). 30 May-23 June. Occasional in open woods and cleared areas. Known from Fort Smith (Thormin), Pine Lake (Kuyt) and Shell Pit (Smith). Material from northeastern Alberta probably belongs to ssp. borealis.

NORTHERN CLOUDY WING (Thorybes pylades). 30 May-27 June. A common species of open mixed woods and roadsides. Known from Fort McMurray (Ball, Brown), Fort Smith (Kuyt, Thormin), Gregoire Lake (Smith), Mildred Lake (HR), Smith Portage (Cary), and Shell Pit (Smith)

\section{Papilionidae - Swallowtails}

HUDSONIAN OLD WORLD SWALLOWTAIL (Papilio machaon hudsonianus).

Reported from Fort Chipewyan by McDunnough and Bowman without mention of date, collector, or location of voucher specimen. ${ }^{112}$

TIGER SWALLOWTAIL (Papilio glaucus canadensis). 25 May-2 July. Common in areas of aspen and mixed woods. Known from Fort MacKay (Kondla), Fort McMurray (Ball, Brown, Sperling), Fort Smith (Thormin), Gregoire Lake (Smith), Mildred Lake (HR, Otto), Peace Point (Gautreau), Pine Lake (Kuyt), Shell Pit (Smith), Slave River 50 miles north of Fort Chipewyan (Cary), Smith Portage (Cary) and Stoney Mountain (Sperling).
Pieridae - Whites, Sulphurs and Marbles

CALIFORNIA WHITE (Pieris sisymbrii flavitincta). 4-8 June. An occasional species of river banks and roadsides. Known from Fort Chipewyan (Cary) and Pine Lake (Kuyt).

WESTERN CHECKERED WHITE (Pieris occidentalis occidentalis). 10 July. Known only from a collection made at Mildred Lake (Otto).

MUSTARD WHITE (Pieris napi oleracea). 10 May-29 July. A common species of open aspen and mixed woods. Known from Ells River (HR), Fort MacKay (Kondla), Fort McMurray (Ball), Fort Smith (Thormin), Gregoire Lake (Smith), House River (Cinnamon), Mildred Lake (HR, Otto), Pine Lake (Kuyt), Shell Pit (Smith), Smith Portage (Cary), Stoney Mountain (Sperling), and Thickwood Hills (HR).

CABBAGE WHITE (Pieris rapae). 2 June-15 July. Occasional in disturbed areas. Known from Fort McMurray (Brown) and Gregoire Lake (Smith).

HECLA SULPHUR (Colias hecla). 29 June. Known from a collection made at the Ells River (HR). Probably the subspecies hela which was described from Churchill, Manitoba. If the latter, it is new to Alberta.

ALFALFA BUTTERFLY (Colias eurytheme eurytheme). 2-25 August. Material that may belong to this migrant butterfly is known from the House River (Cinnamon) and Shell Pit (Smith). The distinction between it and Colias alexandra christina is sometimes not clear cut.

YELLOW ALFALFA BUTTERFLY (Colias philodice eriphyle). 29 May-18 July. Occasional in disturbed areas. Known from Fort McMurray (Ball, Brown, HR, Sperling), Fort Smith (Thormin) and Gregoire Lake (Smith).

PINK-EDGED SULPHUR (Colias interior interior). 3-31 July. Common in open woods and along roadsides. Known from Fort Mackay (HR), Mildred Lake (HR, Otto) and the Thickwood Hills ( $H R$, Otto).

GIANT SULPHUR (Colias gigantea gigantea). 23 June-18 July. An occasional species of bogs, fens and wet 
woods. Known from the Ells River (HR), Fort MacKay (HR), Fort Smith (Kuyt, Thormin) and Gregoire Lake (Smith).

CHRISTINA SULPHUR (Colias alexandra christina). 10 May-7 August. A common species of open woods and river banks. Known from Fort Mackay (HR), Fort McMurray (Ball, Porter), Fort Smith (Bogaert, Kuyt, Thormin), Mildred Lake (Otto), Pine Lake (Kuyt), Shell Pit (Smith), and Smith Portage (Ross).

CREUSA MARBLE (Euchloe creusa). 17 May-8 June. Material from Pine Lake (Kuyt) and Shell Pit (Smith) extends the known range of this species to the northeast.

LARGE MARBLE (Euchloe ausonides). 19 May-13 June. Occasional to common in open woods and along streams and roads. Known from Fort Mackay (Kondla), Fort McMurray (Brown), Mildred Lake (HR, Otto), Pine Lake (Kuyt), and Smith Portage (Cary). Local material may belong to ssp. ausonides, ssp. mayi or may be in a blend zone between the two.

\section{Lycaenidae - Gossamer-winged Butterflies}

HOARY ELFIN (Callophrys polios obscurus). 21 May-23 June. Common in jackpine woods near its food plant, bearberry. Known from Fort Mackay (HR), Mildred Lake (HR, Otto) and Pine Lake (Kuyt).

BROWN ELFIN (Callophrys augustinus augustinus). 1 May-23 June. Common in dry areas near its food plant, bearberry. Known from Fort Chipewyan (Cary), Fort Mackay (Kondla), Fort Smith (Thormin), Gregoire Lake (Smith), Mildred Lake (HR, Otto), Pine Lake (Kuyt), Shell Pit (Smith), Smith Portage (Cary), Stoney Mountain (Sperling), and Thickwood Hills (HR).

EASTERN PINE ELFIN (Callophrys niphon clarki). 1-6 June. This rare species of jack pine woods was first reported for Alberta by Reist (1979). Known from Pine Lake (Kuyt). Incorrectly reported as C. eryphon by Philip based on a 1973 collection from Pine Lake by Elsie Kuyt. ${ }^{13}$

BRONZE COPPER (Lycaena thoe). 16-30 July. A rare species of wet meadows. Known from Fort McMurray (Ball) and
Tar Island (Suncor) (HR).

MARIPOSA COPPER (Lycaena mariposa). 22 June-8 July. Occasional in coniferous woods. Known from Fort McMurray (Brown) and Mildred Lake (HR). The subspecific status is uncertain.

DORCAS COPPER (Lycaena dorcas dorcas). 3 June-2 August. Common in wet woods. Known from Fort Chipewyan (Cary), Fort Mackay (HR), Gregoire Lake (Smith), Mildred Lake (HR, Otto), Shell Pit (Smith), and the Thickwood Hills (HR, Otto).

SCUDDER'S BLUE (Lycaeides argyrognomon scudderii). 23 June-26 July. Occasional in open woods and along roads. Known from Fort Mackay (HR), Fort McMurray (Brown), Fort Smith (Kuyt, Thormin), and Mildred Lake (HR).

GREENISH BLUE (Plebejus saepiolus amica). 17 June-23 July. A species of grassland areas and roadsides. Known from Ells River (HR), Fort MacKay (HR), Fort McMurray (Brown), Fort Smith (Thormin) and the Thickwood Hills (HR, Otto).

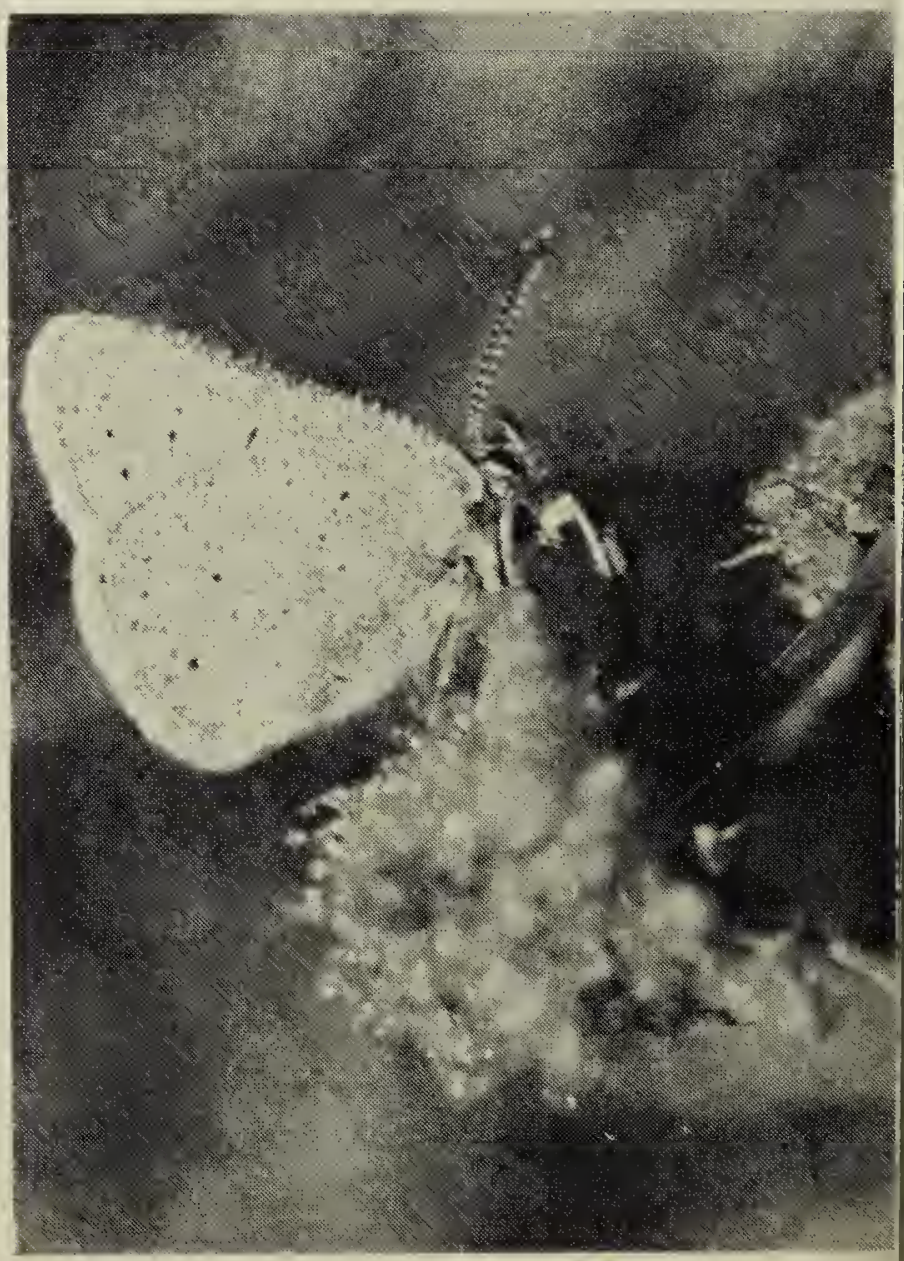

Greenish Blue.

Gary Anweileı 
Lookout (HR), Shell Pit (Smith), and the Thickwood Hills (HR).

MILBERT'S TORTOISE SHELL (Nymphalis milberti furcillata). 31 May-14 August. Occasional in open deciduous woods and disturbed areas. Known from Fort Chipewyan (Russell), Fort Mackay (HR), Fort McMurray (Ball), Fort Smith (Kuyt, Thormin), Gregoire Lake (Smith), and Mildred Lake (HR).

MOURNING CLOAK (Nymphalis antiopa antiopa). 23 June-5 September. Common in deciduous woods and along streams. Known from Fort Chipewyan (Russell), Fort McMurray (Ball), Fort Smith (Thormin), Gregoire Lake (Smith), House River (Cary), Fort Mackay (HR), Pine Lake (Kuyt), and the Thickwood Hills (HR).

SATYR ANGLE WING (Polygonia satyrus satyrus). 10 May-31 June, 26 July-31 August. This common overwintering species occurs in deciduous woods near stinging nettle, its food plant. Known from Fort Chipewyan (Russeli), Fort MacKay (HR), Fort McMurray (Ball, Brown), Mildred Lake (Otto), Pine Lake (Kuyt), and the Thickwood Hills (HR).
GREEN COMMA (Polygonia faunus). 29 May-22 August. Common in deciduous and mixed woods. Known from Athabasca River delta (Cary), Fort Chipewyan (Russell), Fort Mackay (HR), Fort McMurray (Ball, Brown, HR), Gregoire Lake (Smith), Mildred Lake $(H R)$, Pierre au Calumet (Cary), Pine Lake (Kuyt), Shell Pit (Smith), Smith Portage (Cary), and the Thickwood Hills (HR).

HOARY COMMA (Polygonia gracilis). June (no day recorded), 22 August. A rare species of mixed woods. Known from Mildred Lake (Otto), Pine Lake (Kuyt), and the Thickwood Hills (HR).

GRAY COMMA (Polygonia progne). 10 May23 June, 26 July-25 August. An occasional species of mixed woods. Known from Fort McMurray (Ball), Gregoire Lake (Smith), House River (Cinnamon), Fort Smith (Thormin), and Shell Pit (Smith).

PEARL CRESCENT (Phyciodes tharos). 2 June-10 August. Abundant in open woods, clearings, meadows, roadsides and along streams. Known from Fort Mackay (HR), Fort McMurray (Ball,

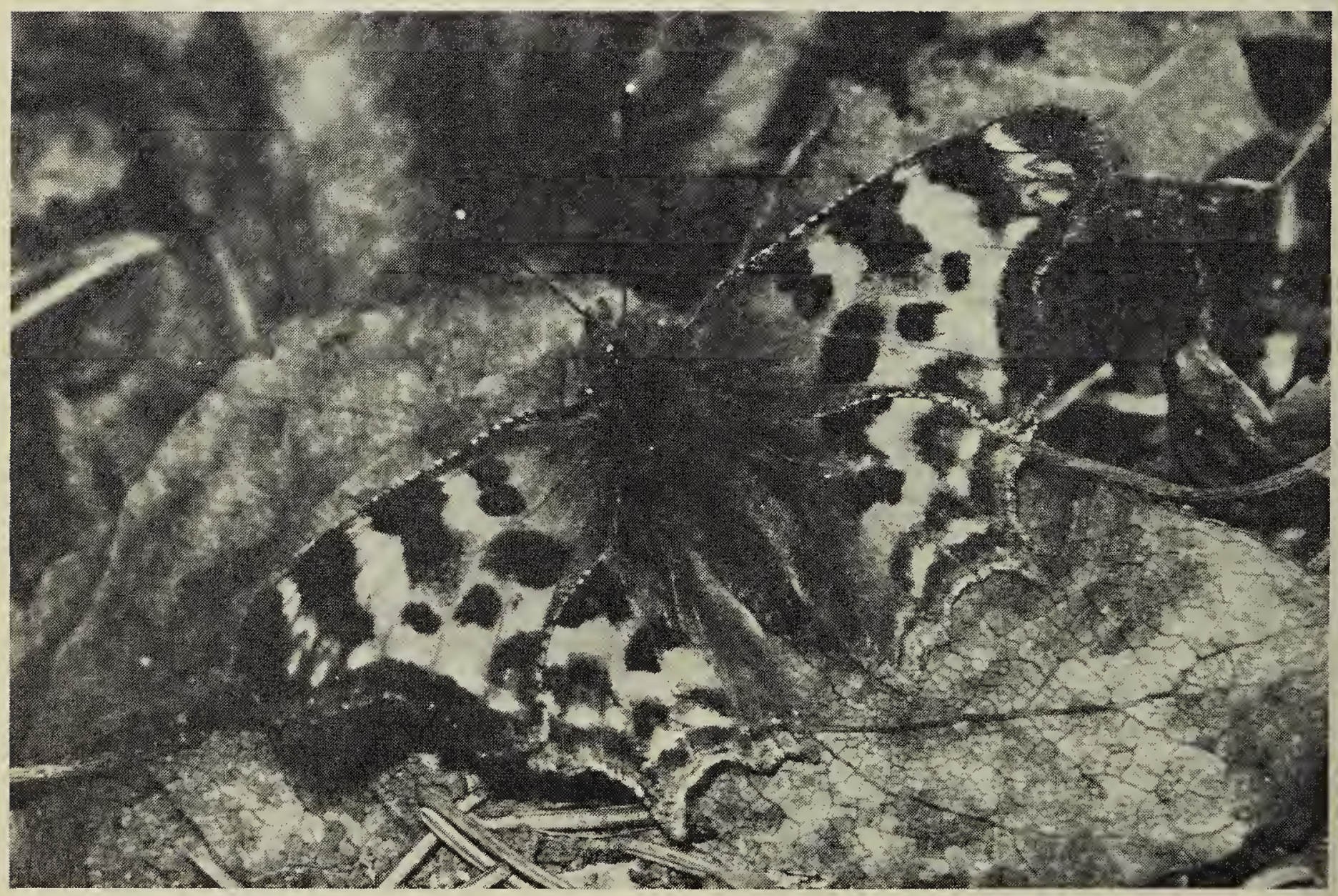


Brown), Fort Smith (Kuyt, Thormin), Gregoire Lake (Smith), House River (Cinnamon), Mildred Lake (HR, Otto), Stoney Mountain Lookout SE of Gregoire Lake (HR), and the Thickwood Hills (HR).

TAWNY CRESCENT (Phyciodes batesii). 20 June 1977. Known from one collection by Smith at Shell Pit. Variability in appearance of the hindwing underside in comparison with eastern populations of this species has led to frequent misidentification of western specimens.

SILVER-BORDERED FRITILLARY (Bo/oria selene). 20 June-3 August. A common species of open woods, roadsides and meadows. Known from Fort McMurray (Ball, Brown), Gregoire Lake (Smith), Mildred Lake (HR), Shell Pit (Smith), and the Thickwood Hills (HR, Otto). The line between ssp. albequina and ssp. atrocostalis occurs in or near northeastern Alberta.

MEADOW FRITILLARY (Boloria bellona jenistai). 4 June-17 August. Found occasionally in meadows and cleared areas. Known from Fort Mackay (Kondla), Fort McMurray (Brown), and Mildred Lake (HR).

\section{FRIGGA FRITILLARY (Boloria frigga saga).}

25 May-24 June. A common species of wet coniferous woods, bogs, and birch and willow fens. Known from Fort Mackay (HR, Kondla), Fort Smith (Thormin), Mildred Lake (HR, Otto), Pine Lake (Kuyt), Shell Pit (Smith), and Stoney Mountain (Sperling).

FREIJA FRITILLARY (Boloria freija freija). 1 May-24 June. A common species of dry willow fens and open coniferous woods. Known from Fort Mackay (HR), Gregoire Lake (Smith), Mildred Lake (HR, Otto), Pine Lake (Kuyt), Smith Portage (Cary), and Stoney Mountain (Sperling).

URPLE LESSER FRITILLARY (Bo/oria titania grandis). 16 July-22 August. A common species of roadsides and clearings in mixed woods. Known from Fort Mackay (HR), Mildred Lake (HR, Otto), Pine Lake (Kuyt), Shell Pit (Smith), and the Thickwood Hills (HR).

OG FRITILLARY (Bo/oria eunomia). 23-25 June. An occasional species of wet coniferous woods and bogs. Known from Fort Mackay (HR), Fort Smith (Thormin), and Mildred Lake (Otto). Regional material could belong to either ssp. dawsoni or ssp. triclaris.

ATLANTIS FRITILLARY (Speyeria atlantis). 5 July-20 August. Abundant throughout the area. Darker individuals of the ssp. hollandi type, appear to be restricted to wet coniferous woods and bogs. Known from Fort Chipewyan (Russell), Fort McMurray (Ball, Brown, Taylor), Gregoire Lake (Smith), House River (Cary, Cinnamon), Mildred Lake (HR, Otto), Shell Pit (Smith), and the Thickwood Hills (HR, Otto).

VARIEGATED FRITILLARY (Euptoieta claudia). 6 July. Rare. Known only from the Thickwood Hills (HR).

Satyridae - Meadow Browns, Arctics and Alpines

OCHRE RINGLET (Coenonympha ochracea mackenziei). 23 June. Uncommon in open grassy areas. Known from Fort Smith (Bogaert, Thormin). New to Alberta, this species has been collected by Elsie Kuyt on 4 and 6 July 1974 at Fort Smith, N.W.T. just north of the Alberta border. It was described from material taken by J. Russell at Nyarling River, N.W.T., on 4 July $1926 .{ }^{5}$ T. C. Emmel states that it occurs "in the vicinity of Great Slave Lake in the Mackenzie District". 9

SMALL WOOD NYMPH (Cercyonis oetus charon). A fresh male labelled "McMurray, 6 July 1953, G. E. Ball" is in the Canadian National Collection. This is a considerable range extension to the northeast. Further documentation is needed to establish the status of the species in the area.

MACOUN'S ARCTIC (Oeneis macounii). 6 June-10 July. Locally common in coniferous woods. Known from Fort McMurray (Ball, Brown), Fort Smith (Thormin), Mildred Lake (HR, Otto), and Shell Pit (Smith). All collections have been made in odd-numbered years (1953, 1977, 1979, 1981). John Masters (1974) has stated that the "insect flies only in odd-numbered years from the Riding Mountains west". 
CHRYXUS ARCTIC (Oeneis chryxus caryi). 10-23 June. An occasional species of coniferous woods. Known from Fort Mackay (Kondla), Fort McMurray (Brown), Mildred Lake (HR), and Smith Portage (Cary). The subspecies caryi was described (Dyar 1904) from material collected by M. L. Cary at Smith Landing on 13 June, 1903.

JUTTA ARCTIC (Oeneis jutta). 30 May-24 June. An occasional species of wet coniferous woods and bogs. Known from Fort Mackay (HR, Kondla), Fort Smith (Thormin), Mildred Lake (HR, Otto), and Shell Pit (Smith). Material from the area may belong to ssp. ridingiana.

DISA OR MANCINUS ALPINE (Erebia disa mancinus). 30 May-4 July. Common in wet coniferous woods. Known from Fort Mackay (HR, Kondla), Fort Smith (Thormin), Mildred Lake (HR, Otto), Peace Point (Gautreau), Pine Lake (Kuyt), Shell Pit (Smith), Stoney Mountain (Sperling), and the Thickwood Hills (HR).

RED-DISKED ALPINE (Erebia discoidalis). 4 May-12 June. Common near wet meadows. Known from Fort McMurray (Brown, HR). Mildred Lake (HR, Otto), Pine Lake (Kuyt), Shell Pit (Smith), and Smith Portage (Cary). Local material may belong to either ssp. mcdunnoughi or ssp. discoidalis. W. Kirby described the latter in 1837 in John Richardson's "Fauna Boreali-Americani" from material collected at Cumberland House, Saskatchewan, while C.F. dos Passos described the former from White Horse, Alaska, and mentions its distribution as "further west in Alberta and extending northward to Alaska". ${ }^{6}$ The differences between the two are slight and primarily involve the "red-disk". Kirby described it as "reddish-tawny" in discoidalis while dos Passos refers to it as "hazel" in mcdunnoughi.

\section{Hypothetical Species}

EYED BROWN (Lethe eurydice eurydice). Merritt Cary reports that he saw an individual at Smith Landing on 12 June 1903. There is no voucher specimen at the United States National Museum and, as there are no other reports, the species should be regarded as hypothetical for the area.

\section{Specimen Location}

The specimens of B. Otto, N.G. Kondla, F.A. H. Sperling and $T$. Thormin are in their collections, while those of W. W. Smith and Elsie Kuyt are at the University of Calgary. The specimens of G.J. Hilchie and J.K. Ryan are deposited in a synoptic collection of insects of the Alberta Oil Sands Environmental Research Program (AOSERP), a butterfly display box for AOSERP and in the private collection of G. J. Hilchie. The G. E. Ball, W. J. Brown, J. Russell and G. Cinnamon specimens are in the Canadian National Collection. M. L. Cary's specimens are at the United States National Museum.

\section{Acknowledgements}

The curators of the above collections are thanked for making their facilities open for study.

BUTLER, A. G. and W. F. KIRBY. 1893. List of insects collected by Miss Elizabeth Taylor in western North America in the summer of 1892. Lepidoptera. Annals and Magazine of Natural History, Ser. 6, 12: 11-21.

${ }^{2}$ BOWMAN, K. 1944. Additions and corrections to the check list of the Macrolepidoptera of Alberta. Canadian Entomologist 76: 191-192.

${ }^{3}$ CARY, M. L. 1907. On the diurnal Lepidoptera of the Athabasca and Mackenzie region, British America. Proceedings of the U.S. National Museum 31(1488): 425-457.

${ }^{4}$ CASE, J.W. and C. D. BIRD. 1977. Butterflies and skippers of west-central Alberta. Blue Jay 35(4): 208-219.

${ }^{5}$ DAVENPORT, D. 1936. A new American Coeononympha (Lepid., Satyridae). Canadian Entomologist 68: 79.

${ }^{6}$ DOS PASSOS, C.F. 1940. A riew subspecies of Erebia discoidalis Kirby (Rhopalocera: Satyridae). Amer. Museum Novitates 1053.

7 DYAR, H. G. 1904. Two new forms of Oeneis Hubner. Proceedings of the Entomological Society of Washington 6: 142. 
${ }^{3}$ FREEMAN, T. N. 1939. Notes on the distribution of Plebeius aquilo Bdv. with the description of a new race from Manitoba (Lepid., Lycaenidae). Canadian Entomologist 71: 178-180.

${ }^{9}$ HOWE, W. H. (ed.). 1975. The butterflies of North America. Doubleday, Garden City, N.Y.

${ }^{10}$ MASTERS, J.H. 1974. Biennialism in Oeneis macounii (Satyridae). Journal of the Lepidopterists' Society 28(3): 237 242.

McDUNNOUGH, J. 1934. Notes on Canadian diurnal lepidoptera. Canadian Entomologist 66: 81-87.

${ }^{2}$ MILLER, L. D. and F. M. BROWN. 1981. A catalogue/checklist of the Rhopalocera of America north of Mexico. Lepitopterists' Society, Memoir 2.

3 PHILIP, K. W. 1974. The 1973 Field Season Summary, Zone 8. The Far North. Alaska and Northern Canada. News of the Lepidopterists Society No. 2, 1974: 14-15.

${ }^{4}$ RAUP, H.M. 1935. Botanical investigations in Wood Buffalo Park. Nat. Museum Canada, Bull. 74.

${ }^{5}$ REIST, J. D. 1979. Callophrys niphon (Lycaenidae) in Alberta with notes on the identification of $C$. niphon and $C$. eryphon. Journal of the Lepidopterists' Society 33(4): 248-253.

RYAN, J.K., and G. J. HILCHIE. 1981. Report on an Ecological Survey of terrestrial insect communities in the AOSERP study area. Prep. for Alberta Oil Sands Environmental Research Program by McCourt Management Ltd. AOSERP Report 115. 202 pp.

THOMPSON, M. D., M. C. WRIDE and M. E. KIRBY, 1978. Habitat mapping of the AOSERP study area: Phase 1. Prep. for the Alberta Oil Sands Environmental Research Program by Intera Environmental Consultants Ltd. AOSERP Report 31. $134 \mathrm{pp}$.

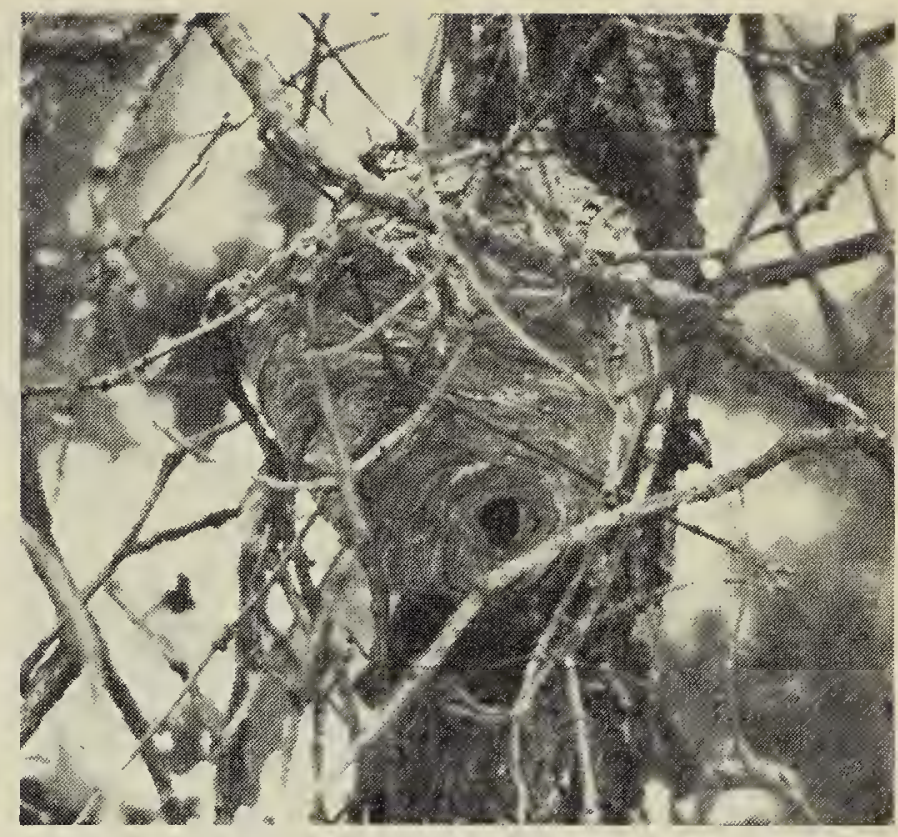

Hornet nest.

B. de Vries

\section{WHITE FACED QUEEN WASP ATTACKS CRANE FLY AT THE PAS}

WALTER KRIVDA, P.O. Box 864, The Pas, Manitoba. R9A $1 \mathrm{~K} 8$

At 8:00 a.m. on 17 June 1982 it was clear, sunny and warm. I observed a white faced wasp pounce on a newly emerged crane fly (tipulidae) on the south side of the house. The wasp flew ahead a bit first, having spotted the crane fly on the wall drying its wings. It then backed up while in flight without turning and swiftly pounced on its prey. Both fell to the ground and rolled around with the wasp making attempts to sting. They were briefly out of view having fallen into a bed of flowering Iris. A moment late the wasp flew up holding the crane fly between her legs, the head foremost and the abdomen hanging between the wasp's legs

In these parts, it is only the females or Queens which overwinter and start their paper nests in early spring. A proteinrich diet may be required to promote rapid growth of the larvae enabling the swift increase in wasp numbers that occurs in our brief summers. 